\title{
Adopting the House of Quality for Improving Services of Nile Cruise Ships in Luxor
}

\author{
Ahmed Adel Hammad \\ Lecturer- Tourism Studies Department \\ Faculty of Tourism and Hotels, Mansoura University, Egypt
}

\author{
Ahmed Anwar Elsaed \\ Lecturer- Hotel Studies Department \\ Faculty of Tourism and Hotels, Mansoura University, Egypt
}

\section{Abstract}

This study aims to develop the House of Quality matrix through which the voice of customers can be transferred to the administration of Nile Cruise ships in Luxor. By developing this matrix, services can be provided in conformity with customer's requirements and expectations. The study presents a suggested matrix of the House of Quality to be applied on Nile cruise ships in Luxor for improving their services. The study depended on primary data through addressing (450) questionnaire forms to customers of Nile cruise ships in Luxor and Cairo in the period December 15, 2019 to January 21, 2020. The study also depended on different sources of secondary data related to its subject. The findings have revealed that customers care firstly about the existence of a skilled staff, followed by a high-quality service. Therefore, the study recommends considering the service quality provided in cruise ships and ensuring that it succeeded in fulfilling what the customer requires.
Keywords: House of Quality, Quality Function Deployment, Service Quality, Nile cruise ships.

\section{Introduction}

In the current growing and competitive world, only efficient and qualified organizations can successfully survive (Kapiki, 2012). The process of developing, implementing and managing new techniques for improving the level of services, increasing customers' numbers and reducing production costs became the main goal of all industries (Kumar, 2019). This study explores how the House of Quality (HOQ) can be adopted as a tool for improving services in the Egyptian tourism and hospitality establishments; applied on Nile cruise ships in Luxor.

The study's core problem lies in finding a balance between the customer's expectations and requirements, and the establishment's capability in achieving them. Therefore, carrying out a study combining those two variables is a key factor for improving the 
quality of services in Nile Cruise ships in Luxor. The importance of study focuses on elaborating criteria, principles and rules for the services provided relying on both of customers' requirements and establishments' capabilities.

Hence, the study aims to identify customers' requirements and their expectations for services provided in Nile cruise ships in Luxor, create a state of balance among their expectations, requirements and the quality of services provided, and finally presenting a proposal on how the House of Quality; HOQ can be applied in these establishments for improving their level of service. Limitations of the study are divided into human limitations and time limitations. Human limitations represented in customers of Luxor and Cairo Nile cruise ships as well as department managers of Nile cruise ships in Luxor. Time limitations represented in addressing questionnaire forms to the mentioned customers and managers in the period from December 7, 2019 to January 21, 2020.

\section{Review of literature:}

\subsection{Quality in Tourism and Hospitality Organizations:}

The evaluation process of service quality has developed over the years (Ganesh and Haslinda, 2014). It relied on three dimensions, which are technical quality, functional quality, and image. The image dimension identifies two basic concepts, which are what service organization provides to customers i.e. services, and how these services are provided. Hence, the SERVQUAL scale was designed to measure customers' expectation about the establishment and their perception of its provided service. This scale relied on a set of dimensions e.g. loyalty, responsiveness, competency, access, courtesy, communication, credibility, security, understanding, and tangibles (Pakurár et al., 2019). For a better understanding of the perceived service quality and customer satisfaction, other attributes have been developed e.g. convenience in making an appointment, friendliness of the staff, the existence of advisors providing accurate information, advisors listening to queries, advisors helping in long term planning, advisors helping to choose the right courses for career, advisors interested in personal life, and finally comes the professionalism in work (Yarimoglu, 2014; Ajmal et al. 2018).

Therefore, it can be inferred that implementing a strategy for quality management is the first step for directing the establishment toward quality (DudekBurlikowska, 2015). Quality is the customer's perception of product and service excellence (Hoe \& Mansori, 2018). Combining services to quality means conformance to specifications as well as the adequacy of service for use (Pheng \& Rui, 2016). Service quality is basically dependent on five dimensions, which are (a) tangibles i.e. physical facilities, equipments, and the personnel appearance; (b) reliability i.e. the company's ability of performing the provided service in a precise way; (c) responsiveness i.e. the company's eagerness in helping customers and providing the best service (Ryglova et al., 2013); (d) assurance i.e. employees' ability to inspire trust depending on competence, credibility and security; and (e) empathy through providing a personalized attention to customers through communication, understanding and access to them (Baki et al., 2009). Therefore, providing high quality services to customers is a key issue for service establishments to build customers' loyalty, create a sustainable competitive advantage, and achieve their profitability and survival (Poor et al., 2013). In order to measure the intangible quality of services, the term Perceived Service Quality 
has been coined. It is the result of comparisons that customers make between their expectations and their perception of the provided service (Yarimoglu, 2014).

\subsection{The House of Quality:}

The Total Quality Management; TQM has emerged as a technique for planning, organizing and understanding each activity in the establishment relying on customers as the central and most important point of operations. It is an integrated management system, which depends on customer's satisfaction through a continuous improvement including all employees of the establishment (Hoe \& Mansori, 2018). In 1965, the Quality Function Deployment; QFD was created as a Japanese strategy for improving processes, enhancing the quality of services and products, and building a competitive advantage so that expectations of customers could be met or exceeded (Erkarslan \& Yilmaz, 2011). It is used as a method to adapt the customer demand for the most appropriate product and service sensibilities (Baran \& Yildiz, 2015). Nowadays, the QFD is utilized as a precise tool for addressing strategic and operational business decisions by translating requirements of customers i.e. the voice of customer; VOC into appropriate technical requirements for stages of production and development (Mehrjerdi, 2010). The QFD can be implemented by deploying the voice of customer in the process of product development depending on a series of one or more matrices.

It has been argued that the HOQ is the main tool of QFD (Paryani, et al., 2010; Chouksey, 2017). It is one of the management techniques that help establishments' managers in improving the quality of their service as well as other related activities (Basri, 2015). It is the most recognized and widely utilized technique for achieving higher customer satisfaction due to its ability in (a) providing communication and interfunctional planning, (b) providing an important source for new investments and potential improvements, calculating benchmarking and prioritization indices, as well as carrying out quality improvement index (Shrivastava, 2015). The HOQ is a correlation between customer requirements and technical characteristics, which can be realized by translating the required service quality into real service quality (Qattawi et al., 2013). Thus, the HOQ matrix relies on six elements, which are (a) identifying customers' requirements and needs i.e. what customers' requirements and needs are and how they can be met, (b) identifying technical solutions i.e. how the customer satisfaction will be created and who will create it, (c) developing a relationship matrix between customer requirements and technical solutions, (d) developing correlation matrix for finding correlation among technical solutions, (e) developing a technical matrix and (f) developing planning matrix (Chouksey, 2017). According to Roikonen (2017), the HOQ matrix includes eight fundamental steps as indicated in the following figure:

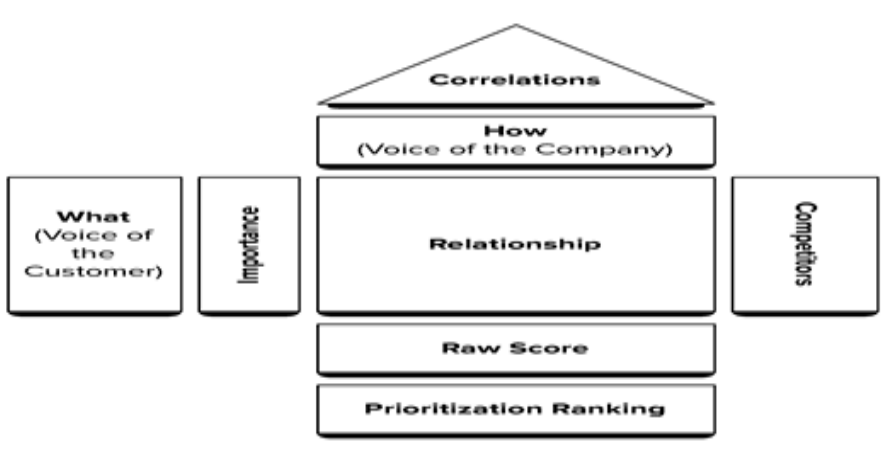

Figure (1): The House of Quality Matrix Source: (Roikonen, 2017)

- Step 1: Identifying Customer Needs 'WHATs': the House of Quality relies fundamentally on customers so that their needs can be clearly identified and determined. Depending on the operationalization of the voice of 
customer, the overall customer concern can be represented effectively (Prasad et al., 2010; Paryani, et al., 2010).

\section{- Step 2: Prioritizing Customer} Needs: the priority structure of customer needs can be developed by assigning different importance weights for customer needs, which are based on QFD team members' experience with customers as well as the results of carried out surveys (Das \& Mukherjee, 2008; Baki et al., 2009).

- Step 3: Comparing the product with other competitive products on different attributes; 'WHATs' (Das \& Mukherjee, 2008).

- Step 4: Listing technical descriptors 'HOWs': by developing relationship matrices between WHATs and HOWs, as well as between every two operating strategies; (HOWs) (Das \& Mukherjee, 2008; Prasad et al., 2010).

- Step 5: Developing a relationship matrix between customer requirements; 'WHATs' and quality characteristics; 'HOWs'. The relationship matrix is utilized to graphically represent the influence degree between each customer requirement and each technical descriptor (Hashemi et al., 2015).

- Step 6: Developing an interrelationship matrix between 'HOWs': The roof of the house of quality is called the correlation matrix, which is attached to technical descriptors. It helps in identifying which technical descriptor does support one another and which does not (Qattawi et al., 2013). A strong positive interrelationship would be a positive correlation whereas a strong negative interrelationship would be a negative correlation (Haung et al., 2013).

- Step 7: Comparing the product with other competitive products on technical descriptors 'HOWs': Subsequently, the competitive assessment of the products is conducted for showing how competitive products are compared with current establishment's products. They are two weighted tables represented into two categories, which are customer assessment and technical assessment (Qattawi et al., 2013). Customer assessment makes up a block of columns corresponding to each customer requirement in the house of quality on the right side of the relationship matrix. The customer competitive assessment is utilized to determine if customer requirements have been met and identify areas to concentrate on in the next design (Haung et al., 2013).

\section{- Step 8: Prioritizing technical} descriptors 'HOWs': the prioritized technical descriptors are a block of rows corresponding to each technical descriptor in the house of qu ality below the competitive assessment. They include a degree of technical difficulty, target value, and relative weights. The needed technical descriptors are identified in order to realize customer requirements and create the desired improvement (Haung et al., 2013).

\subsection{Characteristics of Services in Cruise Ships:}

The service is the process that consists of a series of intangible activities resulting from interactions offered by service providers to 
customers (Kayastha, 2011; Poor et al., 2013). Components of service are an integrated combination of processes, assets, materials and people skills that finally lead to the desired service (Goldstein et al., 2002). Services are characterized by a set of characteristics differentiating them from products e.g. intangibility, inseparability, variability, heterogeneity, perish-ability, instability and dependence on the human factor (Winsor et al., 2004; Das \& Mukherjee, 2008; Albayrak, et al. 2010; Taherdoost et al. 2014; Awara 2014; Jha et al. 2016; Madafuri, 2018). Cruise ships are part of tourism and hospitality industry, which have the same characteristics of other tourism and hospitality entities e.g. travel agencies and restaurants (Najafipour et al., 2014). The change and development in the cruise ship industry is represented in its adaptation to niche markets by designing its onboard products and services to attract a specific target market as well as to accommodate the changing needs of its current customers (Roy \& Véronneau, 2012). They are an amalgam of water transportation that includes travel and tourism services and other onboard services for facilitating tourists' leisure activity (Pallis, 2015). Therefore, trips of cruise ships include a mixture of tangible and intangible benefits e.g. transportation, meals, entertainment, relaxation, escape and socialization (Risitano et al., 2017). Cruise companies can reduce the time spent ashore and encourage tourists to buy goods onboard (Jennings \& Ulrik, 2016). Cruise ships are now witnessing a real noticeable growth in the global tourism industry (Najafipour et al., 2014). They offer tourists a unique onboard experience emerging from the fact that cruise ships are at the same time transportation and accommodation (Radic, et al., 2019). In order to guarantee a high quality in cruise ships' services, some standards have been adopted for achieving that e.g. ensuring the preciseness of the cruise ship program, ensuring safety and security in both of the port's area and onboard, guaranteeing an easy disembarkation, offering modern tourist bus services and facilities, offering high quality shore routes, providing adequate facilities and competent shore operators and paying attention to any extra details (Petreas \& Michalakis, 2009). Therefore, evaluations of cruise ships' services and satisfaction relies on the tourists' experience in entertainment, food, excursion, embarkation and disembarkation, and other services provided by the cruise ship staff ( $\mathrm{Li}$ and Kwortnik, 2016). The rapid growth in cruise tourism obligates suppliers to apply standards of sustainability i.e. suppliers should not only focus on profit, but they should also pay attention to service quality (Sanz-Blas et al., 2019).

\section{Methodology:}

This study aims to design the House of Quality matrix through which the voice of customers can be transferred to the administration of Nile Cruise ships in Luxor. According Thompson (2012), the appropriate equation to determine the sample's size of this research was applied as follows:

N: Sample size, P: Percentage of the purpose of this study $0.50, \mathrm{~d}$ : Percentage of the error limit allowed 0.05, Z: The standard degree used for giving general results is $95 \%$. Thus, the standard degree $=1.96$.

$\mathrm{N}=\frac{250000 \times 0.50(1-0.50)}{\left[250000-1 \times\left(0.05^{2} \div 1.96^{2}\right)+0.50(1-0.50)\right]} \frac{62.500}{162.94}=383.58 \sim 384$

The population of the study is unlimited due to the difficulty of determining a specific number of customers in Nile Cruise ships, so the random sample size is an ideal method to be applied in this study. According to 
Thompson (2012), the minimum number of respondents, that suitable for this study is 384 .

The study relied on utilizing a mixed methodology through incorporating both of primary and secondary data. The secondary sources were discussed above whereas primary data; represented in the quantitive approach were collected and presented after distributing a questionnaire form to a sample of (450) customers of Nile cruise ships in Luxor and Cairo; 250 customers in Luxor and 200 customers in Cairo. The total number of valid questionnaire forms of Nile cruise ships' customers was (207) forms for the sample of Luxor and (184) for the sample of Cairo. Luxor was chosen for carrying out the field study because of its good repute as a unique tourism destination in Egypt (Atef, 2007; Abd Eljalil, 2015). The questionnaire forms consisted of (12) statements aimed at gathering data for comparing between customers' requirements and expectations in the Nile cruise ship in Luxor. They were designed by posing five-point Likert-type scale questions; "very good $=5, \operatorname{good}=4$, neither good nor bad $=3$, bad $=2$ and very $\mathrm{bad}=1$. Results from the valid questionnaire forms were statistically analyzed by using the program of Statistical Package for the Social Sciences "SPSS"; version 25. The analyzed data helped in revealing some important facts concerning the subject of study. The range of each level of agreement was calculated as follows:

- Note that: the mean used in determining the response to the research dimensions is illustrated as follow:

Table 1: The Five Likert Scale Agreement's Levels

\begin{tabular}{|c|c|c|}
\hline Agreement Scale & No. & Range \\
\hline Strongly Disagree & 1 & $1-1.80$ \\
\hline Disagree & 2 & $1.81-2.60$ \\
\hline Neutral & 3 & $2.61-3.40$ \\
\hline Agree & 4 & $3.41-4.20$ \\
\hline Strongly Agree & 5 & $4.21-5$ \\
\hline
\end{tabular}

Note that: the range of each level of agreement was calculated as follow: $5-1 / 5=0.80$

\section{$\underline{\text { Reliability Analysis }}$}

Table 2: Reliability Analysis

\begin{tabular}{|l|l|l|}
\hline City & $\begin{array}{l}\text { Number of } \\
\text { Statements }\end{array}$ & Alpha \\
\hline Luxor & 12 & 0.77 \\
\hline Cairo & 12 & 0.81 \\
\hline
\end{tabular}

Table 2 indicated that alpha coefficient of the questionnaire forms' dimensions was 0.77 for questionnaire statements of Luxor customers', and 0.81 for questionnaire statements of Cairo customers', which are higher than 0.70 (Pallant, 2016). This result indicated to the reliability and validity range of the questionnaire's statements used in this study.

\section{Results and Discussion:}

The results included two main parts; the descriptive analysis, which was used to discover participants' responses, as well as the correlation analysis, which was conducted to examine the relationship between variables and adopting the HOQ matrix. The obtained results were computed and analyzed in the following tables:

The following table (1) illustrates the descending order of the SERVQUAL analysis between both of customers' requirements and their Experience, which is indicated in the following points:

- The requirement of "the Nile cruise ship's cleanliness and modeling" got the highest percentage; representing a relative importance of $9.60 \%$, which indicates that customers pay a full attention to the cruise ship's cleanliness as a key element. On the contrary, customers stated that Luxor cruise ships lack the required cleanliness standard; representing a relative importance of $7.94 \%$.

- The requirement of "staff responses to customer's requests quickly" represented a relative importance of 9.51 , which means that customers are keen on finding an active staff who can always deal with their requests. On 
the other side, customers' answers represented a relative importance of $8.46 \%$ about the responsiveness of Luxor cruise ships' staff's to their requests.

- The requirement of "commitment of providing the complete program of the trip precisely" represented a relative importance of $9.13 \%$, whereas customers' answers about this item applied on Luxor's cruise ships represented a relative importance of $8.23 \%$.

- The requirement of "staff willingness to help customers" represented a relative importance of $9.08 \%$, whereas customers' answers about this item applied on Luxor's cruise ships represented a relative importance of $8.37 \%$.

- The requirement of "staff politeness and courtesy when dealing with customers" represented a relative importance of $8.80 \%$, whereas customers' answers about this item applied on Luxor's cruise ships represented a relative importance of $8.18 \%$.

- The requirement of "trust in staff's skills and qualifications, and the cruise ship's services" represented a relative importance of $8.80 \%$, also providing all services that the customer requires" represented a relative importance of $8.51 \%$, in addition providing customers with a sufficient time for taking care of them" represented a relative importance of $8.23 \%$. Whereas customers' answers about this item applied on Luxor's cruise ships represented a relative importance of $8.46 \%$.

- The requirement of "ensuring the existence of safety and security standards as well as occupational health and safety" represented a relative importance of $7.81 \%$, whereas customers' answers about this item applied on Luxor cruise ships represented a relative importance of $8.04 \%$.

- The requirement of "staff appearance and cleanliness" represented a relative importance of $7.57 \%$, whereas customers' answers about this item applied on Luxor cruise ships represented a relative importance of $8.27 \%$.

- The requirement of "provision of technological services e.g. TV and $\mathrm{WiFi"}$ represented a relative importance of $6.67 \%$ and staff attention and understanding of the special needs of customers" represented a relative importance of $6.29 \%$, whereas customers' answers about this item applied on
Luxor cruise ships represented a relative importance of $8.56 \%$.

Findings of table (1) clarifies the gap between the customers' requirements and their experiences in the investigated cruise ships which may negatively affect on their satisfaction. These findings are consistent with the findings of the study of Ryglova et al. (2013), who stated that, customers' expectations helps in measuring the quality of the provided services. This occurs when the contradiction between these two variables is expressed by customers' satisfaction or dissatisfaction. The study stated that the service quality is dependent on many factors including the management and focused on the staff's efficiency in providing the service in a satisfactory way for customers. 
Table (3): The SERVQUAL Analysis between Customers' Requirements and their Experience

\begin{tabular}{|c|c|c|c|}
\hline \multicolumn{3}{|c|}{ Customer Requirement } \\
\hline $\mathrm{R}$ & $\mathrm{RI} \%$ & $\begin{array}{c}\text { CIR } \\
(1-5)\end{array}$ & $\mathrm{WM}$ \\
\hline 3 & 9.13 & 1.93 & 4 \\
\hline 7 & 8.51 & 1.80 & 3.73 \\
\hline 9 & 7.81 & 1.65 & 3.42 \\
\hline 2 & 9.51 & 2.01 & 4.18 \\
\hline 4 & 9.08 & 1.92 & 3.98 \\
\hline 5 & 8.80 & 1.86 & 3.86 \\
\hline 6 & 8.80 & 1.86 & 3.86 \\
\hline 1 & 9.60 & 2.03 & 4.21 \\
\hline 10 & 7.57 & 1.60 & 3.32 \\
\hline 11 & 6.67 & 1.41 & 2.93 \\
\hline 12 & 6.29 & 1.33 & 2.77 \\
\hline-0
\end{tabular}

\begin{tabular}{|c|c|c|c|c|}
\hline \multirow{2}{*}{\begin{tabular}{c} 
Dimensions/Statements \\
\cline { 2 - 5 }
\end{tabular}} & WM & $\begin{array}{c}\text { CIR } \\
(1-5)\end{array}$ & RI\% & R \\
\hline $\begin{array}{c}\text { Commitment of providing the } \\
\text { complete program of the trip } \\
\text { precisely }\end{array}$ & 3.58 & 1.73 & 8.23 & 9 \\
\hline $\begin{array}{c}\text { Providing all services that the } \\
\text { customer requires }\end{array}$ & 3.68 & 1.78 & 8.46 & 4 \\
\hline $\begin{array}{c}\text { Ensuring the existence of } \\
\text { safety and security standards } \\
\text { as well as occupational health } \\
\text { and safety }\end{array}$ & 3.50 & 1.69 & 8.04 & 11 \\
\hline $\begin{array}{c}\text { Staff responses to customer's } \\
\text { requests quickly }\end{array}$ & 3.68 & 1.78 & 8.46 & 5 \\
\hline $\begin{array}{c}\text { Staff willingness to help } \\
\text { customers }\end{array}$ & 3.64 & 1.76 & 8.37 & 7 \\
\hline $\begin{array}{c}\text { Trust in staff's skills and } \\
\text { qualifications, and the cruise } \\
\text { ship's services }\end{array}$ & 3.57 & 1.72 & 8.18 & 10 \\
\hline $\begin{array}{c}\text { Staff politeness and courtesy } \\
\text { when dealing with customers }\end{array}$ & 3.69 & 1.78 & 8.46 & 3 \\
\hline $\begin{array}{c}\text { The Nile cruise ship's } \\
\text { cleanliness and modeling }\end{array}$ & 3.45 & 1.67 & 7.94 & 12 \\
\hline $\begin{array}{c}\text { Staff appearance and } \\
\text { cleanliness }\end{array}$ & 3.61 & 1.74 & 8.27 & 8 \\
\hline $\begin{array}{c}\text { Provision of technological } \\
\text { services } e . g . \text { TV and WiFi }\end{array}$ & 3.73 & 1.80 & 8.56 & 1 \\
\hline $\begin{array}{c}\text { Staff attention and } \\
\text { understanding of the special } \\
\text { needs of customers }\end{array}$ & 3.72 & 1.80 & 8.56 & 2 \\
\hline $\begin{array}{c}\text { Providing customers with a } \\
\text { sufficient time for taking care } \\
\text { of them }\end{array}$ & 3.68 & 1.78 & 8.46 & 6 \\
\hline Total & ---- & $\mathbf{2 1 . 0}$ & $\mathbf{1 0 0}$ & ---- \\
\hline
\end{tabular}

*WM= Weight Mean

CIR=Customer Importance Rate $\quad{ }^{2} \mathrm{RI}=$ Relative
Table (4): Customers Experience of the Nile Cruise Ships' Competitors

\begin{tabular}{|c|c|c|c|c|c|}
\hline & \multirow[b]{2}{*}{ Dimensions/Statements } & \multicolumn{4}{|c|}{ Customer Experience } \\
\hline & & WM & $\begin{array}{l}\text { CIR } \\
(1-5)\end{array}$ & RI\% & $\mathbf{R}$ \\
\hline \multirow{3}{*}{ 产 } & $\begin{array}{l}\text { Commitment of providing the complete } \\
\text { program of the trip precisely }\end{array}$ & 3.66 & 1.99 & 8.56 & 5 \\
\hline & $\begin{array}{c}\text { Providing all services that the customer } \\
\text { requires }\end{array}$ & 3.73 & 2.02 & 8.72 & 2 \\
\hline & $\begin{array}{c}\text { Ensuring the existence of safety and } \\
\text { security standards as well as } \\
\text { occupational health and safety }\end{array}$ & 3.60 & 31.96 & 8.43 & 6 \\
\hline 童 & $\begin{array}{l}\text { Staff responses to customer's requests } \\
\text { quickly }\end{array}$ & 3.70 & 2.01 & 8.65 & 3 \\
\hline 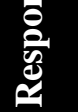 & Staff willingness to help customers & 3.74 & 2.03 & 8.73 & 1 \\
\hline \multirow{2}{*}{ 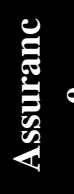 } & $\begin{array}{l}\text { Trust in staff's skills and qualifications, } \\
\text { and the cruise ship's services }\end{array}$ & 3.60 & 1.96 & 8.43 & 7 \\
\hline & $\begin{array}{l}\text { Staff politeness and courtesy when } \\
\text { dealing with customers }\end{array}$ & 3.60 & 1.96 & 8.43 & 8 \\
\hline \multirow{3}{*}{ 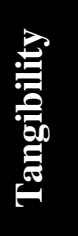 } & $\begin{array}{l}\text { The Nile cruise ship's cleanliness and } \\
\text { modeling }\end{array}$ & 3.69 & 2.01 & 8.64 & 4 \\
\hline & Staff's appearance and cleanliness & 3.52 & 1.91 & 8.22 & 10 \\
\hline & $\begin{array}{c}\text { Provision of technological services e.g. } \\
\text { TV and WiFi }\end{array}$ & 3.53 & 1.92 & 8.26 & 9 \\
\hline \multirow{2}{*}{ 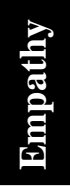 } & $\begin{array}{l}\text { Staff attention and understanding of the } \\
\text { special needs of customers }\end{array}$ & 3.13 & 1.70 & 7.31 & 12 \\
\hline & $\begin{array}{l}\text { Providing customers with a sufficient } \\
\text { time for taking care of them }\end{array}$ & 3.26 & 1.77 & 7.61 & 11 \\
\hline & Total & ---- & 23.25 & 100 & ---- \\
\hline
\end{tabular}

${ }^{1} \mathrm{CIR}=\mathrm{WM} /$ Sample Size $* 100$

${ }^{2} \mathrm{RI}=\mathrm{CIR} / \mathrm{Total} \mathrm{CIR} * 100$ 
As shown in the previous table (3), customers stated that competitive cruise ships are keen on:

- Having staff that is willing to help customers; representing the highest relative importance of $8.73 \%$.

- Providing all services that the customer requires; representing a relative importance of $8.72 \%$.

- Having a staff that is able to respond customer's requests quickly; representing a relative importance of $8.65 \%$.

- Having a cruise ship that is characterized by its cleanliness and modeling; representing a relative importance of $8.64 \%$.

- Commitment of providing the complete program of the trip precisely; representing a relative importance of $8.56 \%$.

- Having staff members that are distinguished by their politeness and courtesy when dealing with customers, the existence of trust in the staff's skills and qualifications as well as in the cruise ship's services and ensuring the existence of safety and security standards as well as occupational health and safety; representing the same relative importance of $8.43 \%$.

- Providing technological services e.g. $\mathrm{TV}$ and $\mathrm{WiFi}$; representing a relative importance of $8.26 \%$.

- Having staff members that are characterized by their good appearance and cleanliness; representing a relative importance of $8.22 \%$.

- Providing customers with a sufficient time for taking care of them; representing a relative importance of $7.61 \%$.

- Having staff members who can pay attention to customers and understand their special needs; representing the lowest relative importance of $7.31 \%$.

By comparing the findings of table (3) and table (4), it was noticed that the quality of services in Cairo cruise ships is better than its counterpart of Luxor cruise ships. This result indicates that Luxor cruise ships need to improve their quality of services in order to continue in competitiveness.

Table (5): The Nile Cruise Ship Evaluation Matrix.

\begin{tabular}{|c|c|c|c|c|c|c|c|c|c|c|}
\hline $\mathrm{R}$ & Customer Requirement & $\begin{array}{l}\text { CIR } \\
(1-5) \\
\end{array}$ & $\begin{array}{l}\text { Customer } \\
\text { Experience }\end{array}$ & $\begin{array}{l}\text { CIR } \\
(1-5) \\
\end{array}$ & $\begin{array}{c}\text { Competitors } \\
\text { Evaluation } \\
\end{array}$ & $\begin{array}{l}\text { CIR } \\
(1-5) \\
\end{array}$ & $\mathbf{P}$ & ${ }^{3} \mathbf{I R}$ & ${ }^{4} \mathbf{R W}$ & $\begin{array}{c}{ }^{5} \text { RIW } \\
\%\end{array}$ \\
\hline 1 & Cruise cleanliness & 2.03 & $\begin{array}{c}\text { Technological } \\
\text { services }\end{array}$ & 1.80 & Willingness to help & 2.03 & 5 & 2.78 & 5.64 & 10.75 \\
\hline 2 & Responsive-ness & 2.01 & $\begin{array}{l}\text { Understanding their } \\
\text { special needs }\end{array}$ & 1.80 & $\begin{array}{l}\text { Meeting their } \\
\text { requirements }\end{array}$ & 2.02 & 5 & 2.78 & 5.59 & 10.66 \\
\hline 3 & Commitment with promises & 1.93 & Staff politeness & 1.78 & Responsive-ness & 2.01 & 4 & 2.25 & 4.34 & 8.28 \\
\hline 4 & Willingness to help & 1.92 & $\begin{array}{l}\text { Meeting their } \\
\text { requirements }\end{array}$ & 1.78 & Cruise cleanliness & 2.01 & 4 & 2.25 & 4.32 & 8.24 \\
\hline 5 & Trust in staff skills & 1.86 & Responsive-ness & 1.78 & $\begin{array}{l}\text { Commitment with } \\
\text { promises }\end{array}$ & 1.99 & 5 & 2.81 & 5.23 & 9.97 \\
\hline 6 & Staff politeness & 1.86 & Taking care of them & 1.78 & Safety and security & 1.96 & 4 & 2.25 & 4.19 & 7.99 \\
\hline 7 & Meeting their requirements & 1.80 & Willingness to help & 1.76 & Trust in staff skills & 1.96 & 5 & 2.84 & 5.11 & 9.74 \\
\hline 8 & Taking care of them & 1.74 & Staff appearance & 1.74 & Staff politeness & 1.96 & 4 & 2.3 & 4 & 7.63 \\
\hline 9 & Safety and security & 1.65 & $\begin{array}{l}\text { Commitment with } \\
\text { promises }\end{array}$ & 1.73 & $\begin{array}{l}\text { Technological } \\
\text { services }\end{array}$ & 1.92 & 4 & 2.31 & 3.81 & 7.26 \\
\hline 10 & Staff appearance & 1.60 & Trust in staff skills & 1.72 & Staff appearance & 1.91 & 4 & 2.33 & 3.73 & 7.11 \\
\hline 11 & technological services & 1.41 & Safety and security & 1.69 & Taking care of them & 1.77 & 4 & 2.37 & 3.34 & 6.37 \\
\hline 12 & $\begin{array}{l}\text { Understanding their } \\
\text { special needs }\end{array}$ & 1.33 & Cruise cleanliness & 1.69 & $\begin{array}{l}\text { Understanding their } \\
\text { special needs }\end{array}$ & 1.70 & 4 & 2.37 & 3.15 & 6.01 \\
\hline \multicolumn{9}{|c|}{ Total of Row Weight } & 52.45 & $100 \%$ \\
\hline
\end{tabular}

*P= Performance Goal $\quad \mathrm{IR}=$ Improvement Ratio $\quad \mathrm{RW}=$ Row Weight RIW= Relative Importance Weight

\footnotetext{
${ }^{3} \mathrm{IR}=$ Performance Goal / customer Experience CIR

${ }^{4} \mathrm{RW}=$ customer requirement $\mathrm{CIR} * \mathrm{IR}$

${ }^{5} \mathrm{RW} /$ Total RW *100
} 
Regarding the customer requirements, the previous table (5) shows the descending order of the gap analysis between customers of Luxor Nile cruise ships and their counterparts of Cairo, as indicated in the following points:

- "The existence of technological services" came in the first place for customers of Luxor Nile cruise ships; representing a CIR of $1.80 \%$, whereas "the staff's willingness to help" came in the first place for their counterparts of Cairo; CIR $=2.03 \%$.

- "Understanding customers' special needs" came in the second place for the customers of Luxor Nile cruise ships; representing a CIR of $1.80 \%$, whereas "meeting customers' requirements" came in the second place for their counterparts of Cairo; representing a CIR of $2.02 \%$.

- "Staff politeness" came in the third place for the customers of Luxor Nile cruise ships; representing a CIR of $1.78 \%$; whereas "responsiveness to customers" came in the third place for their counterparts of Cairo; representing a CIR of $2.01 \%$.

- "Meeting customers; requirements" came in the fourth place for the customers of Luxor Nile cruise ships; representing a CIR of $1.78 \%$, whereas "the cruise cleanliness" came in the fourth place for their counterparts of Cairo; representing a CIR of $2.01 \%$.

- "Responsiveness to customers" came in the fifth place for the customers of Luxor Nile cruise ships; representing a CIR of $1.78 \%$, whereas "the cruise ship's commitment with promises to its customers" came in the fifth place for their counterparts of Cairo; representing a CIR of $1.99 \%$.

- "Taking care of customers" came in the sixth place for the customers of Luxor Nile cruise ships; representing a CIR of $1.78 \%$, whereas "safety and security" came in the sixth place for their counterparts of Cairo; representing a CIR of $1.96 \%$.

- "Staff's willingness to help" came in the seventh place for the customers of Luxor Nile cruise ships; representing a CIR of $1.76 \%$, whereas "trust in staff's skills" came in the seventh place for their counterparts of Cairo; representing a CIR of $1.96 \%$.
- "Staff appearance" came in the eighth place for the customers of Luxor Nile cruise ships; representing a CIR of $1.74 \%$, whereas "staff politeness" came in the eighth place for their counterparts of Cairo; representing a CIR of $1.96 \%$.

- "The cruise ship's commitment with promises to its customers" came in the ninth place for the customers of Luxor Nile cruise ships; representing a CIR of $1.73 \%$, whereas "the existence of technological services" came in the ninth place for their counterparts of Cairo; representing a CIR of $1.92 \%$.

- "Trust in staff skills" came in the tenth place for the customers of Luxor Nile cruise ships; representing a CIR of $1.72 \%$, whereas "staff appearance" came in the tenth place for their counterparts of Cairo; representing a CIR of $1.91 \%$.

- "Safety and security" came in the eleventh place for the customers of Luxor Nile cruise ships; representing a CIR of $1.69 \%$, whereas "taking care of customers" came in the eleventh place for their counterparts of Cairo; representing a CIR of $1.77 \%$.

"The cruise cleanliness" came in the twelfth place for the customers of Luxor Nile cruise ships; representing a CIR of $1.69 \%$, whereas "understanding customers' special needs" came in the twelfth place for their counterparts of Cairo; representing a CIR of $1.70 \%$. 


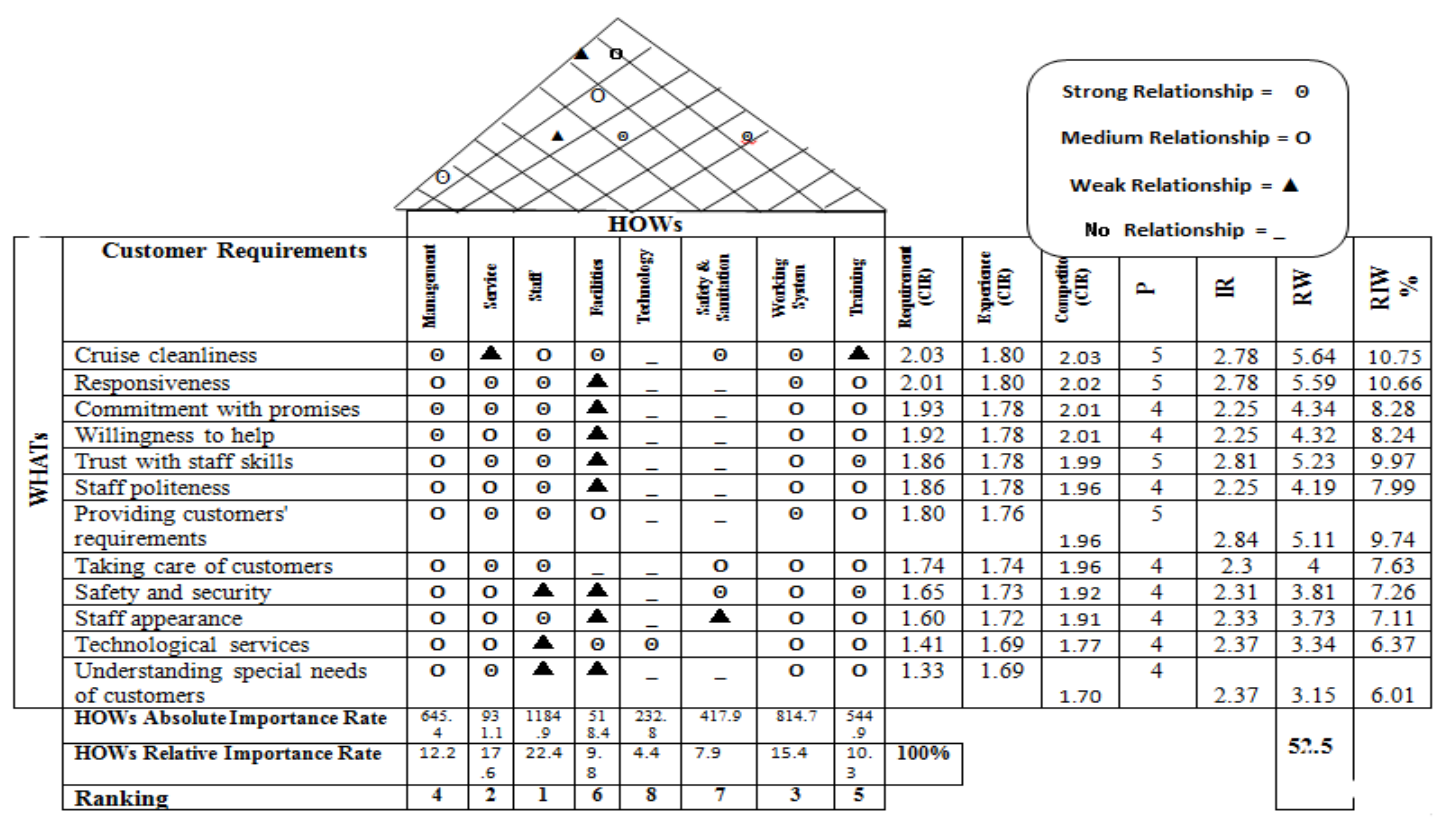

Figure (2): The House of Quality Matrix for Luxor Nile Cruise Ships Source: The Researchers

The previous figure (2) illustrates the items' ranking in the proposed house of quality matrix applied on Luxor Nile cruise ships. The figure indicates that "staff" came in the first place, representing a relative importance of $22.4 \%$, followed by "the service"; representing a relative importance of $17.6 \%$, followed by the "working system"; representing a relative importance of $15.4 \%$. "The management" comes in the fourth place; representing a relative importance of $12.2 \%$, followed by 'the training"; representing a relative importance of $10.3 \%$, followed by "facilities"; representing a relative importance of $9.8 \%$. "The safety and sanitation" comes in the seventh place; representing a relative importance of $7.9 \%$, and finally come the "technology" representing a relative importance of $4.4 \%$.

\section{Conclusion:}

This paper has presented an investigation into the adoption of the House of Quality (HOQ) for improving services of Nile Cruise Ships in Luxor. Regatding theoretical and practical parts of the paper, it was found out that the
HOQ is one of the important modern techniques used to ensure the optimum level of services' quality provided to customers. It depends mainly on understanding what customers need and how to meet these needs efficiently and provide the required services efficiently. Regarding Nile cruise ships in Luxor, it was found out that customers are highly keen on the cleanliness and modeling factor of the cruise ship and always look for a cruise ship which is equipped with technological services. They are also eager to spend their times in a cruise ship whose staff that is always willing to offer help to them. The suggested structure of the HOQ matrix for Luxor cruise ships should firstly include the skilled staff who provides the service to customers, then comes the service itself that should be provided in a high quality, and then comes working system i.e. the working environment that should be equipped to provide a unique service for a memorable holiday. After these mentioned items comes the management of the cruise ship, followed 
by the training it offers to its staff for achieving quality in its provided services, followed by the facilities it includes onboard, then comes the safety and sanitation and finally comes the technology.

\section{Recommendations addressed to cruise ships managers:}

- Adopting the HOQ matrix as a model for achieving an efficient service quality for the services provided.

- Understanding customers' needs and requirements and working towards meeting them efficiently.

- Establishing an administrative division for cruise ships whose staff should be acquainted with the new techniques of service quality e.g. the HOQ.

- Carrying out periodical surveys in order to be fully acquainted with the changes in customers' tastes, desires and motivations.

- Emphasizing the existence of a well skilled staff who can meet customers needs and requirements in a good way.

- Drawing attention to the quality of the service provided and making sure that it succeeded in achieving what the customer needs.

- Ensuring that the working environment of the Nile cruise is capable of providing a distinguished service.

- Informing the organization's staff about the service function as well as the matrix of service and quality.

- Paying attention to the voice of customers, so that their desires and expectations can be tailored and met effectively.

- Adopting tools that help in improving the quality of cruise ships services.
- Making a comparison between organization's products and products of its competitors in the market, in order to identify the products' weaknesses either in quality and/or cost, and tackling them.

\section{References:}

Abd Eljalil, S. G. (2015): Re-profiling the Tourism Products: The Role of Event Tourism Agenda in Luxor, Journal of Arab Universities for Tourism and Hospitality, 9, 1-27.

- Ajmal, H., Khan, R. A. \& Fatima, M. (2018): Impact of Service Quality on Customer Satisfaction in Banking Industry of Pakistan: A Case Study of Karachi, Journal of Social and Administrative Sciences, 5(3), 219-238.

Albayrak, T., Caber, M. \& Aksoy, S. (2010): Relationships of Tangible and Intangible Elements of Tourism Products with Overall Customer Satisfaction, International Journal of Trade, Economics and Finance, 1(2), 140-143.

Atef, T. M. (2007): Evaluating Egyptian Nile Cruises Service Quality, Egyptian Journal of Tourism and Hospitality, 10(2), 1-19.

Awara, N. F. \& Anyadighibe, J. A. (2014): An Appraisal of Strategies and Challeneges of Services Marketing in Globalized Business Environment, International Journal of managerial Studies and Research, 2(9), 32-40.

Baki, B., Basfirinci, C., Ar., I. M. \& Cilingir, Z., (2009): An Application of Integrating SERVQUAL and Kano's Model into QFD for Logistics Services: A Case Study from Turkey, Asia Pacific Journal of Marketing and Logistics, 21(1), 106-126.

Baran, Z. \& Yildiz, M. S. (2015): Quality Function Deployment and Application on a Fast Food Restaurant, International Journal of Business and Social Science, 6(9), 122-131.

- Basri, W. S. (2015): House of Quality as a Quality Tool in Higher Education Management, Journal of Culture Society and Development, 10, 21-24.

Chouksey, A. \& Dalpati, A. (2017): An Application of Quality Function Deployment: A Case of Gymnasium Union Institution for Industrial engineering, Industrial and Engineering Journal, 10(8), 30-36. 
- Das, D. \& Mukherjee, K. (2008): Development of an AHP-QFD Framework for Designing a Tourist Product, International Journal of Services and Development Management, 4(3), 321-244.

Dudek-Burlikowska, M. (2015): The Concept of Total quality Management and the Contemporary Entrepreneurship in practice, Journal of Achievements in Materials and Manufacturing Engineering, 73(2), 229-236.

- Erkarslan, O. \& Yilmaz, H. (2011): Optimization of the Product Design through Quality Function Deployment and Analytical Hierarchy Process: A Case Study of a Ceramic Washbasin, METU Journal of the Fcaulty of Agriculture, 28, 1-22.

- Ganesh, R. \& Haslinda, A. (2014): Evolution and Conceptual Development of Service Quality in Service Marketing and Customer Satisfaction, International Review of Management and Business Research, 3(2), 1189-1197.

- $\quad$ Goldstein, S. M., Johnston, R., Duffy, J \& Rao, J. (2002): The Service Concept: the Missing Link in Service Design Research?, Journal of operations Management, 2(2002), 121-134.

- $\quad$ Hashemi, N., Marzban, M. \& Delavari, S., (2015): Quality Function Deployment: An Application to Chemotherapy Unit Services, Middle East Journal of Cancer, 6(4), 219-228.

- Haung, L. P., Sheng, L. H., Moketar, N. A. \& Khalid, N. S. C., (2013): Quality Function Deployment: Shampoo Product, Project Report, Faculty of Information Technology and Communication, Technical University of Malaysia Malacca, Malaysia, 1-10.

- Hoe, L. C. \& Mansori, S. (2018): The Effects of Product Quality on Customer Satisfaction and Loyalty: Evidence from Malaysian Engineering Industry, International Journal of Industrial marketing, 3(1), 20-35.

- Jennings, H. \& Ulrik, K. (2016): Cruise Tourism: What's Below the Surface?, Research Briefing, Tourism Concern, England, UK.

- Jha, N., Verma, J. P., \& Moitra, R. (2016): Service Marketing, $1^{\text {st }}$ Ed., Himalaya Publishing House, Mumbai, India.

- Kapiki, S. T. (2012): Quality Management in Tourism and Hospitality: An Explorarrtory Study among Tourism Stakeholder, International Journal of Economic Practices and Theories, 2(2), 53-61.
Kayastha, S. (2011): Defining Service and Noservice Exchanges, Service Science, 3(4), 313-324. Available at: https://doi.org/10.1287/serv.3.4.313. Accessed in: October $10^{\text {th }}, 2019 ; 02.10$ AM.

Kumar, R. (2019): Kaizen A Tool for Continuous Quality Improvement in Indian Manufacturing Organization, International Journal of Mathematical, Engineering and Management Sciences, 4(2), 452-459.

Li, Y. \& Kwortnik, R. (2016): Categorizing Cruise Lines by Passenger Perceived Experience, Journal of Travel Research, 1(16), 2-16.

Madafuri, B. (2018): Implication of Characteristics of Tourism Product Towards Marketing Strategy, International Journal of scientific and Technology Research, 7(8), 233-235.

Mehrjerdi, Y. Z. (2010): Quality Function Deployment and Its Extensions, International Journal of Quality and Reliability Management, 27(6), 616-5460.

Najafipour, A. A., Marzi, V. \& Foroozanfar, M. H. (2014): The Future of Cruise Ship Tourism Industry: the Challenges of Cruising Market and Operations Management, Journal of Social Issues and Humanities, 2(1), 213-224.

- Pakurár, M., Haddad, H., Nagy, J, Popp, J. \& Oláh, J. (2019): The Service Quality Dimensions that Affect Customer Satisfaction in the Jordanian Banking Sector, Sustainability, 11, 1113, 1-24.

- Pallant, J. (2016): SPSS Survival Manual, $6^{\text {th }}$ Ed., Berkshire, McGraw-Hill Education, UK.

- Pallis, T. (2015): Cruise Shipping and Urban Development: State of the Art of the Industry and Cruise Ports, Discussion Paper 2015-14, the International Transport Forum, Greece.

- $\quad$ Paryani, K., Masoudi, A. \& Cudney. E. A. (2010): QFD Application in Hospitality Industry: A Hotel case Study, Quality Management Journal, 17(1), 728.

- Petreas, C. \& Michalakis, C. (2009): Shore Activities Characteristics of Cruise Tourism Passengers, World Journal of Tourism, Leisure and Sports, 3(2), 19-29.

- $\quad$ Pheng, L. S. \& Rui, Z. (2016): Service Quality for Facilities Management in Hospitals, Springer, Singapore, DOI 10.1007/978-981-10-0956-3. 
- Poor, M. H., Poor, M. A. \& Darkhaneh, M. A. (2013): The Quality of Service and its Importance in Service Organizations, Arabian Journal of Business and Management Review (Oman Chapter), 3(3), 34-37.

- $\quad$ Prasad, D. K. G. D., Subbaiah, K. V., Rao, K. N. \& Sastry, C. V. R. S., (2010): Prioritization of Customer Needs in the House of Quality using Cojoint Analysis, International Journal of Quality Research, 4(2), 145-154.

- Qattawi, A., Mayyas, A., Abdelhamid, M., \& Omar, M. (2013): Incorporating Quality Function Deployment and Analytical Hierarchy Process in a Knowledge-based System for Automotive Production Line Design, International Journal of Computer Integrated Manufacturing, 26, 1-19.

- Radic, A., Bjork, P. \& Kauppinen-Raisanen, H. (2019): Cruise Holidays: How On-brad Service Quality Affects Passengers' Behavior, Tourism Marine Environments, 14(1-2), 45-59.

- $\quad$ Risitano, M, Sorrentino, A. \& Quintano, A. (2017): Understanding the Role of the Service Experience in the Cruise Industry, Intentional Journal of Tourism Policy, 7(4), 289-308.

- $\quad$ Roikonen, H. (2017): Customer Needs Analysis in Commercialization of LWLC Electrical drives, Master's Thesis, School Business Management, Lappeenranta University of Technology, Finland.

- Roy, J. \& Véronneau, S. (2012): Cruise lines and Passengers, the Blackwell Companion to Maritime Economics, $1^{\text {st }}$ Ed., Blackwell Publishing Ltd., UK.

- Ryglova, K., \& Rašovská, I., \& Šácha, J. (2013): Approaches to Quality Management in Hotel Industry. Acta Universitatis Agriculturae et Silviculturae Mendelianae Brunensis. 61(302), 2693-2699.

- Sanz-Blas, S., Buzova, D. \& Schlesinger, W. (2019): The Sustainability of Cruise Tourism Onshore: The Impact of Crowing on Visitors' Satisfaction, Sustainability, 11, 1510, 1-15.

- Shrivastava, P. (2015): House of Quality: An Effective Approach to Achieve Customer satisfaction and Business Growth in Industries, International Journal of Science and Research, 5(9), 1365-1371.

- Taherdoost, H., Sahibuddin, S. \& Jalaliyoon, N. (2014): Features' Evaluation of Goods, Services and E-Services: Electronic Service Characteristics
Exploration, the $7^{\text {th }}$ International Conference Interdisciplinarity in Engineering (Inter-Eng 2013), Procedia Technology, 12(2014), 204-211.

- Thompson, S. K. (2012): Sampling, $3^{\text {rd }}$ Ed., John Wiley \& Sons, Inc., USA. 59-60.

- Winsor, R. D., Sheth, J. N. \& Manolis, C. (2004): Differentiating Goods and Services, Retailing Using Form and Possession Utilities, Journal of Business Research, 57 (2004), 249-255.

- Yarimoglu, E. K. (2014): A Review on Dimensions of Service Quality Models, Journal of Marketing Management, 2(2), 79-93 